\title{
Meninjau Ulang Ketentuan Presidential Threshold dalam Pemilihan Presiden dan Wakil Presiden*
}

\author{
Aprilian Sumodiningrat** \\ Universitas Gadjah Mada, Yogyakarta, Indonesia
}

\begin{abstract}
The presidential threshold is a requirement for the nomination of the President and Vice President to meet the minimum threshold percentage for support from the DPR or the number of valid national votes. Presidential threshold provisions are contained in various laws and regulations regarding Elections. This research is juridical study using a conceptual approach and statute approach. The legal materials used in this research are primary and secondary legal materials. The two legal materials are inventoried; then used as a basis for compiling a prescriptive study of the legal issues raised. The results of this study state that the presidential threshold has started since 2004. Regulations regarding post-reform elections always include a presidential threshold. Then, the presidential threshold has been 'tested' several times by the Constitutional Court. Various decisions of the Constitutional Court stated that the presidential threshold is one of the provisions which is the domain of open legal policy for legislators or the making of laws. Furthermore, the implication of the presidential threshold is aimed at simplifying the fragmentation of political parties in parliament. The nominations for the President and Vice President promoted by the parliamentary political party actually allow for more than two candidates; and it is also possible to have an Election that does not get the support of more than 50 persen of the voters' vote. Thus, effectiveness is needed regarding the implementation of the presidential threshold provisions in the presidential system by strengthening relations between presidential institutional actors and the President's non-institutional personnel.
\end{abstract}

KEYWORDS: Presidential Threshold, General Election, Open Legal Policy.

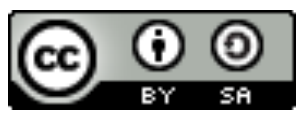

Copyright $\odot 2021$ by Author(s)

This work is licensed under a Creative Commons Attribution-ShareAlike 4.0 International License. All writings published in this journal are personal views of the authors and do not represent the views of this journal and the author's affiliated institutions.

\section{HOW TO CITE:}

Sumodiningrat, Aprilian, "Meninjau Ulang Ketentuan Presidential Threshold dalam Pemiliban Presiden dan Wakil Presiden di Indonesia" (2021) 1:1 Jurnal Kajian Pembaruan Hukum 49-74. DOI: <https://doi.org/10.19184/jkph.v1i1.23349>.

Submitted: 24/02/2021 Reviewed: 29/02/2021 Revised: 10/03/2021 Accepted: 15/03/2021

* Tulisan ini dikembangkan dari tugas akhir pada Fakultas Hukum Universitas Jember berjudul, "Penentuan Presidensial Threshold dalam Pemilihan Umum Presiden dan Wakil Presiden di Indonesia."

** Corresponding authors' e-mail: hackaprilian@gmail.com 


\section{PENDAHULUAN}

Perdebatan panjang mengenai sistem Pemilihan Presiden dan Wakil Presiden (Pilpres) di dalam Pasal 6A Undang-undang Dasar Negara Republik Indonesia 1945 (UUD 1945) memerlukan waktu hingga empat tahun pembahasan; yang pada akhirnya berujung kesepakatan Majelis Permusyawaratan Rakyat (MPR) untuk melakukan pemurnian sistem pemerintahan presidensial. ${ }^{1}$ Dinamika pembahasan terkait sistem Pilpres berdasarkan perubahan UUD 1945 dimulai pada saat pembentukan Undang-Undang Nomor 23 tahun 2003 tentang Pemilihan Umum Presiden dan Wakil Presiden (UU Pilpres I). Pasal 6A(2) UUD 1945 menyatakan bahwa "pasangan calon presiden dan wakil presiden diusulkan oleh partai politik dan/atau gabungan partai politik peserta pemilu sebelum pelaksanaan pemilihan umum" melahirkan batas minimal partai politik peserta pemilihan umum untuk dapat mencalonkan presiden dan wakil presiden (presidential threshold) yang tercantum dalam UU Pilpres $\mathrm{I}{ }^{2}$ dengan ketentuan setidaktidaknya memperoleh 15 persen dari jumlah kursi di DPR atau 20 persen suara sah nasional dalam pemilu legislatif. ${ }^{3}$

Sejak norma presidential threshold tersebut berlaku dan dipertahankan hingga pada Undang-Undang Nomor 7 tahun 2017 tentang Pemilihan Umum (UU Pemilu), terdapat banyak gugatan berkali-kali ke Mahkamah Konstitusi (MK) untuk dapat menganulir ketentuan ini; diantaranya dalam perkara: 51/PUU-VI/2008, 52/PUU-VI/2008, dan 59/PUU-VI/2008 yang menguji konstitusionalitas ketentuan presidential threshold dalam Pasal 9 UndangUndang Nomor 42 Tahun 2008 tentang Pemilihan Umum Presiden dan Wakil Presiden (UU Pilpres II). ${ }^{4}$ Selanjutnya, di bawah rezim UU Pemilu, pengujian terhadap ketentuan terkait presidential threshold dalam Pasal 222 UU Pemilu terdapat dalam permohonan Nomor 51-52-59/PUU-VI/2008; kembali dipertahankan dalam Putusan MK Nomor 53/PUU-XV/2018. ${ }^{5}$

1 Saldi Isra, Sistem Pemerintahan Indonesia, 1st ed (Depok: RajaGrafindo Persada, 2019) at 234.

2 Ibid at 236.

3 Ibid.

4 Ibid at 241.

5 Ibid at 245. 
Penelitian mengenai presidential threshold sejatinya telah dilakukan oleh dua peneliti sebelumnya. Penelitian pertama dilakukan oleh Abdul Ghoffar (2018) mengenai problematika presidential threshold: putusan Mahkamah Konstitusi dan pengalaman di negara lain; yang secara garis besar menyatakan bahwa presidential threshold tidak diperlukan. ${ }^{6}$ Penelitian kedua dilakukan oleh Sholahuddin Al-Fatih (2019) mengenai akibat hukum regulasi tentang threshold dalam: pemilihan umum legislatif dan pemilihan presiden; yang menyatakan bahwa ketentuan tentang presidential threshold tidak perlu diterapkan pula. ${ }^{7}$ Kedua penelitian tersebut berbeda dengan penelitian berjudul, "Meninjau Ulang Ketentuan Presidential Threshold dalam Pemiliban Presiden dan Wakil Presiden di Indonesia”; oleh sebab penelitian ini memberikan telaah dan sudut pandang terkait politik hukum dibalik ketentuan presidential thresold. Penelitian ini akan menguraikan dan menganalisis aspek-aspek politik hukum, sejarah, dan pengaruh pengaturan presidential threshold terhadap efektivitas pemerintahan presidensial; sehingga akan memberikan perbedaan tersendiri bagi penelitian sebelumnya yang mendukung atau tidak mendukung ketentuan presidential threshold.

\section{METODE}

Penelitian ini merupakan penelitian yuridis normatif yang menggunakan pendekatan konseptual dan peraturan perundang-undangan. ${ }^{8}$ Bahan hukum yang digunakan adalah bahan hukum primer dan bahan hukum sekunder; yang diinventarisir dan kemudian dikaji untuk mendapatkan preskripsi mengenai kerangka politik hukum, aspek sejarah, dan risalah pembentukan undang-undang yang mewarnai dan mendasari ketentuan presidential threshold. Setelah mendapatkan preskripsi, hasil kajian dijelaskan secara sistematis untuk menjawab isu hukum yang diangkat.

6 Abdul Ghoffar, "Problematika Presidential Threshold: Putusan Mahkamah Konstitusi dan Pengalaman di Negara Lain” (2018) 15:3 J Konstitusi 480-501.

7 Sholahuddin Al-Fatih, "Akibat Hukum Regulasi tentang Threshold dalam Pemilihan Umum Legislatif dan Pemilihan Presiden: (2019) 12:1 J Yudisial 17.

8 Peter Mahmud Marzuki, Penelitian Hukum: Edisi Revisi (Jakarta: Kencana, 2017). 


\section{ASPEK HISTORIS KETENTUAN PRESIDENTIAL THRESHOLD DI INDONESIA}

Setiap Undang-Undang (UU) memiliki suatu aspek historis mengenai proses dan perjalanan suatu norma yang ada didalamnya yang dibentuk ataupun dipertahankan. ${ }^{9}$ Pada proses tersebut, terdapat banyak pertentangan ataupun perbedaan pendapat yang biasanya lumrah terjadi di dalam parlemen. ${ }^{10}$ Pada sisi lain, dapat dipastikan terdapat pro dan kontra mengenai suatu peraturan yang baru akan ditetapkan atau tetap dipertahankan; terlebih partai pemerintah dan partai oposisi memiliki keyakinan dan dalih pembenar masing-masing. ${ }^{11}$ Perihal meninjau sebab-akibat lahirnya suatu UU sejatinya dapat didasarkan atas naskah akademik dan perbandingan sistem yang ada dari tahun-tahun sebelumnya; terlebih ketika norma tersebut memang merupakan norma pada suatu UU di tahun-tahun sebelumnya. Mengenai ketentuan presidential threshold sejatinya telah berlaku sejak tahun 2004; manakala ketika itu pula merupakan momentum hajat besar bagi rakyat Indonesia untuk menyelenggarakan Pilpres secara langsung. ${ }^{12}$ Pada tahun ini pula lahir suatu lembaga independen untuk menyelenggarakan Pemilihan Umum (Pemilu); yaitu Komisi Pemilihan Umum (KPU). ${ }^{13}$

Pada tahun 2004, presidential threshold ditetapkan sebesar 15 persen dari jumlah kursi Dewan Perwakilan Rakyat (DPR); atau setara dengan 20 persen suara nasional. Sedangkan pada tahun 2009, Pasal 9 UU Pilpres II menetapkan presidential threshold sebesar 20 persne suara DPR atau setara dengan 25 persen suara sah nasional; yang mana pada saat itu Pemilu dilaksanakan dengan dua tahapan. Pada pelaksanaan Pilpres tahun 2014, ketentuan presidential threshold tetap menggunakan sebagaimana ketentuan yang tercantum dalam UU Pilpres II; yaitu 20 persen suara DPR atau 25

\footnotetext{
9 Aaron Gordon, "Nondelegation” (2019) 12:3 NYU J Law Lib 799.

10 Jonathan H Alder \& Christopher J Walker, "Delegation and Time" (2019) 105 Iowa Law Rev 7.

11 Tuswoyo, "Pelembagaan Oposisi Dalam Sistem Presidensial: Studi Tentang Oposisi PDIP di DPR" (2013) 1:1 JISPO (Jurnal Ilmu Sos dan Ilmu Polit) 132-155 at 137.

12 Ghoffar, supra note 6 at 481.

13 Sarjan Sarjan, Kemal AL Kindi Mulya \& Siti Chadijah, "Problematika Dan Teknis Penyelengaraan Pemilihan Kepala Daerah Pada Masa Pandemi Covid 19" (2020) 3:1 Rechtsregel J Ilmu Huk 59.
} 
persen suara sah nasional. Selanjutnya, pada perhelatan Pilpres di tahun 2019, regulasi mengenai Pemilu diatur dengan UU Pemilu; dengan ketentuan mengenai presidential threshold terdapat pada Pasal $222 \mathrm{UU}$ Pemilu. Presidential threshold ditentukan sebesar 20 persen suara DPR atau 25 persen suara sah nasional dengan sistem Pemilu yang dilaksanakan secara serentak dan ketentuan ambang batas tersebut diambil dari tahun sebelumnya (Pemilu 2014). Hal ini tentunya merupakan sebuah pembeda yang amat krusial yang ditunjukkan dari tahun-tahun sebelumnya mengenai regulasi tentang presidential threshold tersebut. ${ }^{14}$

Pada naskah komprehensif buku 10 mengenai Perubahan UUD 1945, terdapat usulan Agun Gunanjar Sudarsa yang menegaskan bahwa terhadap Pasal 37(1), (2), dan (3) UUD 1945 disetujui dan disepakati untuk dirubah oleh sebab menyangkut masalah perubahan pasal-pasal di dalam konstitusi; yang harus setidak-tidaknya diajukan oleh sepertiga dari jumlah anggota MPR. Selanjutnya, Agun Gunanjar Sudarsa juga menyatakan bahwa esensi dari usulan tersebut adalah mengenai masalah Pasal 6A(4) UUD 1945 yang ketika itu di dalam pembahasannya masih menunjukkan dua alternatif; apakah akan dikembalikan rakyat atau dipilih oleh MPR. Perihal usulan Pasal 37 dan 6A UUD 1945 tersebut disampaikan bahwa untuk memperoleh jumlah sepertiga di dalam tatanan sistem politik yang menganut sistem multipartai dirasa akan menjadi sangat sulit. Terlebih, sistem kepartaian kedepan akan semakin mengkristal dan hanya partai partai yang legitimate yang dapat mengikuti dan bersaing di periode-periode Pemilu selanjutnya. ${ }^{15}$

Pendapat Agun di atas menjadi salah satu rujukan untuk mempertahankan presidential threshold yang secara eksplisit menyatakan bahwa kedepannya partai-partai akan mengkristal dan diasumsikan bahwa prasyarat paket Calon Presiden dan Wakil Presiden harus memenuhi ambang batas 35 persen; yang nantinya ketentuan tersebut diharapkan dapat

14 Ayon Diniyanto, "Mengukur Dampak Penerapan Presidential Threshold di Pemilu Serentak Tahun 2019” (2018) 1:1 Indones State Law Rev 83-90.

15 Tim Penyusun Naskah Komprehensif dan Proses dan Hasil Perubahan UUD 1945, Naskah Komperehensif Perubahan Undang-Undang Dasar Negara Republik Indonesia tabun 1945 Buku X Perubahan, Aturan Peralihan, dan Aturan Tambahan, Edisi Revisi (Sekretariat Jendral dan Kepaniteraan Mahkamah Konstitusi, 2010), hlm. 104-106. 
mengkonsolidasikan partai-partai menjadi semakin sederhana. Prasyarat 35 persen presidential threshold sebenarnya diajukan dan dipikirkan untuk mewujudkan sistem presidensial yang efektif; agar tidak terjadi kesulitankesulitan teknis penyelenggaraan Pemilu. Prasyarat presidential threshold 35 persen yang dimaksud ketika itu tentunya dapat diusulkan oleh partai politik atau gabungan partai politik. ${ }^{16}$ Namun, pada Pemilu yang diselenggarakan tahun 2004, syarat ambang batas tersebut diimplementasikan secara bertahap; yaitu sebesar 15 persen suara parlemen atau setara 20 persen suara sah nasional, hingga pada Pemilu 2019 mencapai angka 20 persen suara parlemen atau setara 25 persen suara nasional. ${ }^{17}$

Mahkamah Konstitusi (MK) juga telah beberapa kali mengeluarkan putusan terkait pengujian materiil presidential threshold ${ }^{18}$ diantaranya dalam Putusan Mahkamah Konstitusi (PMK) No. 51-52-59/PUU-VI/2008 tertanggal 18 Februari 2009, PMK No, 14/PUU-XI/2013 tertanggal 23 Januari 2014, PMK No. 108/PUUXI/2013 tertanggal 11 Februari 2014, PMK No. 53/PUU-XV/2017 tertanggal 19 Desember 2017. Seluruh pengujian terkait presidential threshold tersebut menyatakan bahwa presidential threshold adalah sah dan konstitusional untuk dipertahankan (terakhir dalam PMK No 53/PUU-XV/2017). MK juga menyatakan bahwa pengaturan terkait presidential threshold merupakan open legal policy; yang bebas ditentukan oleh pembuat UU atau Legislative (dalam PMK No. 108/PUU-XI/2013). Pada PMK No. 14/PUU-XI/2013 yang didalamnya mengujikan Pasal 3(5), Pasal 9, Pasal 12(1) dan (2), Pasal 14(2) dan Pasal 112 UU Pilpres II, MK tidak memberikan putusan mengenai Pasal 9 UU Pilpres II yang mengatur tentang presidential threshold. Selain itu, amat penting untuk dipahami bahwa Pasal 3(5) UU Pilpres II mengenai pelaksanaan Pemilu dua tahap; yaitu Pilpres dilaksanakan setelah pemilihan DPR, DPD, dan DPRD diberikan ketetapan oleh MK bahwa pasal tersebut inkonstitusional. Pasal-pasal yang

16 Mushaddiq Amir, "Keserentakan Pemilu 2024 yang Paling Ideal Berdasarkan Putusan Mahkamah Konstitusi Republik Indonesia” (2020) 23:2 Al-Ishlah J Ilm Huk 115131.

17 Titon Kurnia, "Presidential Candidacy Threshold and Presidentialism Affirmation in Indonesia" (2021) 07:03 Padjajaran J Ilmu Huk (Journal Law) 353-379.

18 Kuswanto Kusnadi, "Mahkamah Konstitusi dan Upaya Menegakkan Asas Presidensialisme di Indonesia” (2020) 5:1 Refleks Huk J Ilmu Huk 1-20. 
dikabulkan oleh MK dalam PMK No. 14/PUU-XI/2013 yaitu adalah Pasal 3(5), Pasal 12(1) dan (2), Pasal 14(2), dan Pasal 112 UU Pilpres II.

Perihal PMK No. 14/PUU-XI/2013, jika diperhatikan secara parsial akan berimbas dan mengganggu jalannya Pemilu 2014 yang akan segera berjalan ketika itu. ${ }^{19}$ Oleh karenanya, atas pertimbangan untuk tidak mengganggu jalannya Pemilu 2014 yang akan dilaksanakan ketika itu, maka di dalam amar putusan angka dua, MK menyatakan bahwa amar putusan dalam angka 1 PMK No. 14/PUU-XI/2013 berlaku untuk penyelenggaraan Pemilu tahun 2019 dan Pemilu seterusnya. Hal tersebut berarti ketentuan pelaksanaan Pemilu setelah PMK No. 14/PUU-XI/2013 tetap dilaksanakan sesuai dengan UU dan ketentuan yang lama. Sedangkan pembatalan Pasal 3(5) UU Pilpres II oleh PMK No. 14/PUU-XI/2013 dipergunakan untuk Pemilu di tahun 2019 dan berlaku pula untuk Pemilu seterusnya. Selain itu, dalam amar putusan pangkat 3 PMK No. 14/PUU-XI/2013, MK menegaskan untuk menolak permohonan pemohon untuk selain dan selebihnya. Hal tersebut dimaksudkan oleh MK bahwa Pasal 9 UU Pilpres II yang tidak dimasukkan ke dalam amar putusan untuk tetap dipertahankan. ${ }^{20}$ Alasan MK mempertahankannya karena ini merupakan ranah pembentuk UU; yang menetapkan pula ketentuan persyaratan perolehan suara partai politik sebagai syarat untuk menjadi mengajukan pasangan calon presiden dan wakil presiden. Selain itu, persyaratan pada Pasal 9 UU Pilpres II merupakan kebijakan hukum yang terbuka; yang pada hakikatnya tidak lah berkaitan dengan pemilihan secara serentak atau tidak.

Pada tahun 2017-2018, MK kembali menetapkan PMK mengenai ketentuan presidential threshold dalam UU Pemilu. Pada Putusan No. 53/PUU-XV/2017, MK menolak permohonan para pemohon. Pengujian yang diwakili oleh 12 orang itu menghasilkan PMK No. 53/PUU-XV/2017; yang menyatakan bahwa kewenangan untuk menentukan prasyarat atau

19 Dewa Putu Wahyu Jati Pradnyana, I Gede Yusa \& Ni Luh Gede Astariyani, “Analisa Hukum Ambang Batas Pencalonan Presiden (Presidential Threshold) dalam UndangUndang Republik Indonesia Nomor 7 Tahun 2017 Tentang Pemilihan Umum” (2018) 6:4 Kertha Negara J Ilmu Huk 1-13.

20 M Rizky Andika Pratama Putra Effendhy \& Moh Haris Lesmana, "Formulasi Konsep Single Presidential Treshold dalam Pemilu Serentak sebagai Upaya Memperkuat Sistem Pemerintahan Presidensial di Indonesia" (2019) 2:2 Legislatif 1-23. 
ambang batas pencalonan Presiden dan Wakil Presiden merupakan open legal policy. ${ }^{21}$ Oleh karena itu, aspek historis dari penerapan sistem presidential threshold dimulai sejak diterapkannya electoral treshold (Pemilu 2004); hingga muncul berbagai pengujian terkait ketentuan ambang batas pencalonan presiden dan wakil presiden, dan pada akhirnya ketentuan ini tetap dipertahankan oleh MK sampai saat ini.

\section{OPEN LEGAL POLICY LEGISLATIF DALAM PENENTUAN PRESIDENTIAL THRESHOLD}

Legal drafting merupakan tindakan yang tidak memiliki dasar atau landasanlandasan apapun dalam pengaturan akan hal-hal yang menjadi muatan serta materi dalam UU yang akan dibentuk itu. ${ }^{22}$ Namun sering kali, pemaknaan legal drafting selalu diajarkan secara sempit; yaitu pembentukan peraturan perundang-undangan. ${ }^{23}$ Pembentukan perundang-undangan dalam arti sempit, memiliki norma-norma tertentu yang menjadi acuan dasar penormaan suatu UU. Hal tersebut dikenal sebagai die Theorie Vom Stufendornung der Rechsnormen (teori hierarki atau jenjang norma atau stufenbautheory); ${ }^{24}$ sebagaimana yang diutarakan oleh Hans Kelsen serta oleh Hans Nawiasky. Gagasan tersebut pada pokoknya menyatakan bahwa dalam pembentukan hukum yang lebih rendah, harus didasarkan kepada hukum yang lebih tinggi; begitu sebaliknya, hukum yang tertinggi akan menjadi dasar atau acuan di dalam pembentukan norma baru yang lebih rendah kedudukannya. Oleh karena itu, semakin rendah sifat suatu norma; maka semakin teknis substansi pengaturannya. Sebaliknya juga, semakin tinggi posisi suatu norma; maka sifatnya akan semakin abstrak. ${ }^{25}$

21 Taufiqurrohman Syahuri \& Muhammad Helmi Fahrozi, "Konstitusionalitas Pasal 222 UU Nomor 7 Tahun 2017 Tentang Pemilu (Presidential Treshold)" (2020) 1:1 Al Wasath J Ilmu Huk 25-34.

22 Lutfil Ansori, Legal Drafting (Teori dan Praktik Penyusunan Perundang-Undangan) (Depok: PT RajaGrafindo Persada, 2019).

23 Ibid.

${ }^{24}$ Mardian Wibowo, "Menakar Konstitusionalitas sebuah Kebijakan Hukum Terbuka dalam Pengujian Undang-Undang” (2016) 12:2 J Konstitusi 196.

25 Ibid. 
Pada beberapa PMK, MK menyatakan terdapat norma yang merupakan suatu ranah kebijakan hukum terbuka bagi legislator atau pembuatan UU; ${ }^{26}$ yang sering digaungkan dengan istilah open legal policy. Apabila suatu norma mengandung kebijakan hukum terbuka, maka MK akan menilai norma tersebut berada di dalam wilayah yang konstitusional, bersesuaian, dan tidak bertentangan dengan UUD 1945. PMK yang memberikan penilaian kebijakan hukum terbuka terhadap suatu norma di dalam UU diantaranya: PMK No. 10/PUU-III/2005, PMK No. 16/PUU-V/2007, PMK No. 5152-59/PUU-VI/2008, PMK No. 3/PUU-VII/2009, PMK No. 86/PUUX/2012, PMK No. 02/PUU-XI/2013, PMK No. 38/PUU-XI/2013, PMK No. 73/PUU-XII/2014.

Pada bidang ilmu hukum, open legal policy memanglah hal yang sangat baru dan tidak pernah dikenal sebelumnya; justru yang lumrah kita kenal adalah istilah policy atau dikenal dengan kebijakan. ${ }^{27} \mathrm{Di}$ sisi lain, policy tak jarang juga dikenal sebagai communitarian policy, public policy, sosial policy. Ketiga istilah tersebut memiliki makna yang memang sudah bebas; karena setiap makna kebijakan akan menggambarkan keleluasaan pejabat yang berwenang dalam melakukan dan menentukan pelaksanaan pelaksanaan yang belum diatur secara jelas di dalam UU. ${ }^{28}$

Hakikatnya UU disusun dan dibentuk dengan menerapkan prinsip fleksibelitas sebagai salah satu refleksi tanggung jawab negara; ${ }^{29}$ dengan kata lain tujuan dibentuknya suatu UU adalah agar dapat senantiasa bersesuaian dengan keadaan masyarakat. Di sisi lain, UU harus mudah untuk diterapkan di dalam suatu masyarakat yang memiliki banyak perbedaan dari berbagai aspek. Namun demikian, penerapan kebijakan hukum tidak dapat disamakan dengan prespektif kebijakan publik. Oleh sebab, diantara dua bidang tersebut (kebijakan publik dan kebijakan hukum) terdapat berbagai dimensi dari aspek aktualisasi; yang akan saling bertolak belakang pula.

26 Iwan Satriawan \& Tanto Lailam, “Open Legal Policy dalam Putusan Mahkamah Konstitusi dan Pembentukan Undang-Undang" (2019) 16:3 J Konstitusi 559-584 at 572 .

${ }^{27}$ Ibid at 561.

28 Wibowo, supra note 24.

${ }^{29}$ Muhammad Fadli, "Pembentukan Undang-Undang yang Mengikuti Perkembangan Masyarakat” (2018) 15:1 J Legis Indones 49-58. 
Beberapa PMK yang memiliki suatu kebijakan hukum terbuka seperti di atas, juga dapat diartikan sebagai suatu kebebasan bagi pembuat UU untuk menentukan suatu materi muatan dalam bentuk kebijakan hukum.

PMK 14/PUU-XI/2013 dalam perkara pengujian UU Pilpres II yang dimohonkan oleh Efendi Gazali -sebagai pemohon- adalah salah satu keputusan yang mengandung konsepsi kebijakan hukum terbuka. Pada PMK 14/PUU-XI/2013, MK berpendapat bahwa Pasal 22E (6) UUD 1945 memberikan kewenangan kepada pembentuk UU atau legislator (DPR bersama Presiden) untuk mengatur tata cara pelaksanaan Pilpres. Hal tersebut merupakan ranah kebijakan hukum terbuka dan kewenangan legislator untuk merumuskan mekanisme terbaik mengenai tata cara Pilpres; dan tidak termasuk di dalamnya mengenai penentuan waktu suatu Pemilu dengan pilihan yang lain. Kebijakan hukum terbuka ditetapkan oleh MK adalah Pasal 9 UU Pilpres II yang menyatakan:

"Pasangan Calon diusulkan oleh Partai Politik atau Gabungan Partai Politik peserta pemilu yang memenuhi persyaratan perolehan kursi paling sedikit 20 persen (dua puluh persen) dari jumlah kursi DPR atau memperoleh 25 persen (dua puluh lima persen) dari suara sah nasional dalam Pemilu anggota DPR, sebelum pelaksanaan Pemilu Presiden dan Wakil Presiden."

Dengan demikian, Pasal 9 UU Pilpres II tidak membatasi dengan serentak atau tidaknya suatu pemilihan umum, baik pemilihan anggota perwakilan legislatif atau pemilihan presiden. Di sisi lain, Pasal 22E(6) UUD 1945 telah memberikan kewenangan terbuka secara delegatif dan kewenangan terbuka dalam penentuan; apakah presidential threshold akan tetap dipertahankan ataukah akan dihapuskan dalam Pemilu serentak dan sepenuhnya hal tersebut merupakan kewenangan legislator sebagai pembentuk UU.

MK sebagai pengawal konstitusi tidak akan membatalkan UU apabila didalamnya secara substantif materi muatan-nya merupakan kewenangan penuh yang diberikan secara delegasi kepada legislative untuk membentuk suatu legal policy; terlepas dari penilaian baik buruknya suatu aturan yang ditentukan oleh legislator. Dengan demikian, penilaian terhadap suatu UU bukan berarti hal tersebut merupakan muatan yang inkonstitusional; kecuali apabila kebijakan hukum yang diambil akan melanggar suatu moralitas, 
rasionalitas, dan ketidakadilan yang tidak dapat ditoleransi. Apabila dirujuk ke belakang terkait usulan mengenai ambang batas pencalonan Presiden dan Wakil Presiden, dapat ditemukan dalam Surat Presiden Republik Indonesia No: R.02/PU/I/2003 (Surpres UU Pilpres I) kepada parlemen terkait usulan dalam pembahasan RUU Pemilihan Presiden dan Wakil Presiden.

Surpres UU Pilpres I yang menunjukkan bahwa ambang batas pencalonan presiden awalnya adalah usulan yang diajukan oleh pemerintah ke dalam naskah rancangan UU Pilpres I, pada tanggal 28 Januari 2003. Pasal 5(4) naskah usulan tersebut menyatakan:

"Proses lanjut usulan pasangan calon oleh partai politik atau gabungan partai politik hanya dapat dilakukan oleh partai politik atau gabungan partai politik peserta pemilihan umum anggota DPR yang memperoleh suara dalam pemilihan umum secara kumulatif nasional sekurangkurangnya 20 persen."

Usulan yang digagas di atas banyak menuai pro dan kontra dalam parlemen. Terdapat sejumlah fraksi yang cenderung bersikap kontra, diantaranya seperti Fraksi Perserikatan Daulat Umat (F-PDU), dan Fraksi Partai Bulan Bintang (F-PBB), Fraksi Reformasi (F-Reformasi), Fraksi Kesatuan Kebangsaan Indonesia (F-KKI), Fraksi Kebangkitan Bangsa (F-KB), ${ }^{30}$ serta pandangan dari Lembaga Ilmu Pengetahuan Indonesia (LIPI); ${ }^{31}$ yang kemudian juga disepakati oleh Fraksi Partai Persatuan Pembangunan (FPPP). ${ }^{32}$ Lebih lanjut bahkan, Jimly Asshidiqie (Universitas Indonesia) menegaskan prasyarat ambang batas 20 persen tidak diperlukan jika dilakukan dua tahap, akan tetapi jika untuk membatasi jumlah calon; syarat tersebut masih dapat dipertimbangkan dan tak harus 20 persen. ${ }^{33}$ Sedangkan Fraksi Partai Golkar (F-PG), Fraksi Partai Demokrasi Indonesia Perjuangan (F-PDIP) dan Fraksi TNI/Polri menginginkan syarat tersebut berlaku.

Merespon berbagai keberatan yang muncul terkait presidential threshold, Menteri Dalam Negeri kala itu, Hari Sabarno menjelaskan bahwa angka 20

30 DPR RI, Risalah Rapat Proses Pembahasan Rancangan Undang-Undang tentang Pemilihan Presiden dan Wakil Presiden (Jakarta, 2003) at 7.

31 Ibid at 30.

32 Ibid at 45.

33 Ibid at 65. 
persen tersebut adalah untuk mengatur jumlah ideal peserta Pilres. Syarat terkait presidential threshold tersebut juga dimaksudkan untuk membangun stabilitas pemerintahan dalam konteks hubungan Presiden dan DPR. Dukungan 20 persen dari kursi DPR merupakan modal awal Presiden untuk membangun sinergi dengan DPR, dan bukan bertujuan untuk menghabisi partai politik yang ada. ${ }^{34}$ Namun demikian, pada akhirnya presidential threshold disepakati untuk ditunda pelaksanaannya hingga Pemilu tahun 2009. Kesepakatan tersebut justru tidak membuat pengaturan presidential threshold tersebut dihilangkan dalam pilpres 2004; hanya saja angkanya yang diturunkan menjadi 3 persen kursi DPR atau 5 persen perolehan suara sah hasil Pemilu legislatif. 35

Berdasarkan hasil kesepakatan di atas, ${ }^{36}$ norma presidential threshold yang akan diberlakukan untuk Pemilu 2009 tercantum dalam Pasal 5(4) UU Pilpres I. Sementara, norma presidential threshold untuk Pemilu 2004 tercantum dalam Pasal 101 UU Pilpres I. Norma presidential threshold pada Pemilu tahun 2019 tetap dipertahankan; sebagaimana Pasal 222 UU Pemilu. ${ }^{37}$ Bahkan, syarat ambang batas diperberat menjadi 20 persen suara parlemen atau 25 persen suara sah secara nasional; dengan merujuk pada perolehan Pemilu 2014. Beberapa pengujian perihal ketentuan tersebut sempat ditolak oleh MK. Namun, berbeda dengan Saldi Isra yang memilih dissenting opinion dalam putusan tersebut. Saldi Isra menjelaskan bahwa pada pokoknya, jika partai politik di DPR sama dengan partai politik presiden, atau mayoritas partai di parlemen mendukung presiden; maka praktik sistem presidensial akan rawan terperangkap menjadi pemerintah otoriter. ${ }^{38}$

${ }^{34}$ Isra, supra note 1 at 239.

35 Ibid.

36 Ibid.

37 Sukimin Sukimin, "Pemilihan Presiden Dan Wakil Residen Berdasarkan UndangUndang Republik Indonesia Nomor 7 Tahun 2017 Tentang Pemilihan Umum" (2020) 3:1 J USM Law Rev 112.

38 Isra, supra note 1. 


\section{PRESIDENTIAL THRESHOLD DAN IMPLIKASINYA TERHADAP PENYEDERHANAAN PARTAI POLITIK}

Pada sistem dua partai besar seperti yang dijalankan di Amerika Serikat, kemungkinan untuk terjadi banyaknya calon dapat dipastikan tidak akan terjadi; mengingat hanya akan ada dua calon yang akan diajukan. ${ }^{39}$ Namun, pada sistem multi-partai, paket calon Presiden memungkinkan lebih banyak daripada dua calon; serta memungkinkan pula juga terjadinya Pemilu yang tidak mendapatkan dukungan lebih dari 50 persen suara pemilih. ${ }^{40}$ Dalam rangka Pilpres secara langsung, pada konstitusi Perancis misalnya; ${ }^{41}$ terdapat pengaturan mengenai second round election atau pemilihan putaran kedua yang dilakukan apabila pada tahap pertama tidak diperoleh dukungan lebih dari 50 persen suara. Kemudian, tahap kedua dengan mengikutkan dua pasangan calon yang mendapatkan suara tertinggi dalam pemilihan pertama. Pada tahap pemilihan pertama dan tahap pemilihan kedua tersebut, pemilihan sama-sama dipilih langsung oleh rakyat. Namun, mekanisme yang seperti itu dinilai akan sangat 'memakan' banyak biaya; apalagi bagi negara-negara berkembang seperti indonesia yang dapat dinilai tidak praktis dan tidak efisien.

Sistem presidensial yang diterapkan bersamaan dengan sistem multipartai dapat dianggap kurang cocok di Indonesia. Di samping itu, Indonesia telah memasuki era demokratisasi, sehingga banyaknya partai juga tidak dapat dan tidak mungkin lagi untuk dibatasi seperti pada masa orde baru. ${ }^{42}$ Maka dari itu, diperlukan mekanisme pengaturan yang dapat membuat partai politik tersebut juga secara alamiah dapat berkurang dengan sendirinya; tanpa adanya larangan ataupun pembatasan yang bersifat imperatif. Namun, dalam realitas dan kenyataan sistem dua partai tentu tidak dapat terwujud di

39 Aisah Putri Budiatri, "Pemilu Presiden Amerika Serikat" (2013) 10:2 J Penelit Polit 163-175.

40 Ahmad Farhan Subhi, "Pengusulan Pasangan Calon Presiden dan Wakil Presiden Sebagai Peserta Pemilu Menurut Undang-Undang Pilpres” (2016) 3:2 J Cita Huk 339-352.

41 Dri Utari C R, "Menakar Kohabitasi Perancis dalam Mekanisme Koalisi Oposisi Pasca Pemilu Serentak 2019” (2020) 3:1 J Jentera 261-290.

42 Andrian Habibi, "Upaya Menyelamatkan Pemilihan Umum di Tahun 2020" (2020) 4:1 Adalah Bul Huk Keadilan 167-172. 
Indonesia apabila berkaca dari kemajemukan masyarakat dan bangsa Indonesia yang sangat kompleks. ${ }^{43}$ Tidak akan realistis apabila membayangkan bahwa suatu saat nanti hanya akan ada dua partai besar di indonesia. Terlepas dari kemungkinan-kemungkinan tersebut, upaya penyederhanaan jumlah partai politik amat diperlukan jika Indonesia bermaksud untuk menerapkan sistem presidensial secara murni dengan cara memilih Presiden dan Wakil Presiden oleh rakyat secara langsung.

Masa transisi demokrasi di Indonesia pada akhirnya selesai di tahun 2004; bersamaan dengan amandemen keempat UUD 1945 yang dilakukan pada tahun 1999 hingga 2002 serta telah dilaksanakan Pilpres secara langsung pula di tahun 2004. Sistem politik telah banyak dirubah, kekuatan yang seimbang antara eksekutif, legislatif, dan yudikatif telah dirancang dan diimplementasikan sedemikian rupa dengan sangat hati-hati sebagai wujud untuk menghindari bangkitnya kembali otoritarianisme rezim. ${ }^{44}$ Namun, beberapa sarjana hukum berargumen bahwa sistem politik Indonesia masih legislative heavy; ${ }^{45}$ manakala sejak seorang presiden seringkali menjadi sandera politik dan mengalami banyak kendala dalam pembuatan kebijakan oleh parlemen parlemen. Pendapat yang lain adalah bahwa sistem politik Indonesia masih dalam kategori executive heavy; ${ }^{46}$ karena di sisi lain Presiden memiliki kekuatan untuk melakukan legislasi melalui Perppu; ${ }^{47}$ meski tanpa persetujuan DPR dalam keadaan terdesak.

Perihal menakar kuat atau lemahnya kekuasaan presiden; tidak cukup kita hanya mempelajari tentang institusi Presiden semata. Kekuatan dan

43 Indarja Indarja, "Perkembangan Pemilihan Presiden dan Wakil Presiden di Indonesia" (2018) 47:1 Masal Huk 63.

44 Bayu Dwi Anggono, "Perspektif Konstitusi Indonesia pada Kerjasama Partai Politik dalam Pemilihan Presiden dan Wakil Presiden” (2014) 9:1 Pandecta Res Law J 92112.

45 Koichi Kawamura, "President Restrained: Effects of Parliamentary Rule and Coalition Government on Indonesia's Presidentialism" in Pres Assem Policy-making Asia (London: Palgrave Macmillan UK, 2013) 156.

46 Sulkiah Sulkiah, "Pelaksanaan Hak Prerogatif Presiden dalam Penyusunan Kabinet Berdasarkan Pasal 17 UUD 1945 Amandemen Suatu Tinjauan Sistem Ketatanegaraan Indonesia" (2020) 2:1 Nurani Huk 42.

47 Mohammad Zamroni, "Kekuasaan Presiden dalam Mengeluarkan Perppu (President's Authority to Issue Perppu)” (2015) 12:3 J Legis Indones 1-38. 
kelemahan dari Presiden itu sendiri sangat berkorelasi dengan institusi politik yang lain. ${ }^{48}$ Apabila kita ingin mengukur sejauh mana kekuasaan presiden memberi keputusan atas kebijakannya sendiri, kita harus menganalisis pula hubungan antara institusi Presiden dan parlemen yang memegang kekuasaan legislatif. Kita harus melihat kepada kewenangan legislasi yang dimiliki Presiden, selain itu juga kepada kekuatan politik yang dipegang oleh presiden (partisan politik) untuk mendapatkan dukungan di dalam parlemen. ${ }^{49}$

Pada masa reformasi, hubungan antara Presiden dan legislatif telah mengalami pergantian. Pada amandemen pertama konstitusi di tahun 1999, telah ditetapkan bahwa DPR harus memegang otoritas terhadap pembuatan UU; ${ }^{50}$ sedangkan Presiden memiliki hak memberikan Rancangan UndangUndang (RUU) terhadap DPR. Amandemen tersebut mencabut hak presiden dalam penetapan UU; meski amandemen UUD 1945 tetap mempertahankan hak Presiden untuk mengajukan RUU. Di samping itu, dalam hal lain, Presiden membutuhkan persetujuan atau konsultasi dengan parlemen dalam penetapan duta besar konsuler serta lembaga administratif independen; seperti bank sentral atau KPU, begitu pula dengan pemberian gelar dan penghargaan-penghargaan lainnya. Hak veto Presiden pada konstitusi sebelum amandemen juga telah di hapuskan di dalam amandemen kedua UUD 1945. ${ }^{51}$ Sehingga, RUU akan otomatis diundangkan atau menjadi UU dalam 30 hari setelah selesai dibahas; meskipun Presiden tidak mengesahkannya pula. ${ }^{52}$ Oleh karena itu, Presiden tidak memiliki veto untuk menolak RUU.

48 Cipto Prayitno, "Analisis Konstitusionalitas Batasan Kewenangan Presiden dalam Penetapan Peraturan Pemerintah Pengganti Undang-Undang” (2020) 17:3 J Konstitusi 513-529.

49 Kawamura, supra note 46.

50 Bayu Dwi Anggono, "Tertib Jenis, Hierarki, dan Materi Muatan Peraturan Perundang-Undangan: Permasalahan dan Solusinya" (2018) 47:1 Masal Huk 1-9.

51 La Ode Muhammad Elwan, "Penataan Ulang Sistem Legislasi: "Efektifitas Hak Veto Presiden Dalam Sistem Pemerintahan di Indonesia Berdasarkan UUD NRI Tahun 1945" (2018) 4:3 Rezpublica 1-13.

52 Bayu Dwi Anggono, Perkembangan Pembentukan Undang Undang di Indonesia (Jakarta: Penerbit Konstitusi Press, 2014). 
Kendati demikian, Presiden dapat berpartisipasi dalam pembahasan RUU di dalam parlemen; karena RUU tidak bisa selesai dibahas di dalam parlemen tanpa adanya persetujuan Presiden. Pada kasus ini, konstitusi telah menetapkan bahwa setiap RUU harus didiskusikan bersama oleh Presiden dan DPR untuk mencapai persetujuan bersama. ${ }^{53}$ Ketika Presiden atau parlemen tidak menyetujui RUUyang di ajukan oleh Presiden atau parlemen; maka RUU tersebut tidak akan dapat diwujudkan dalam pembahasan di parlemen, sehingga RUU itu dinyatakan batal. Meskipun setelah amandemen konstitusi, Presiden tidak memiliki veto terhadap RUU yang selesai dibahas di dalam parlemen; namun Presiden memiliki veto di dalam pembahasan RUU.

Saat ini Presiden masih memiliki kekuatan veto yang efektif, meskipun tidak didefinisikan secara jelas dalam konstitusi. Selain itu, Presiden tidak memiliki kewenangan untuk membatasi revisi di dalam parlemen terhadap Rancangan Anggaran Pendapatan dan Belanja Negara (RAPBN) atau untuk menyatakan referendum nasional. ${ }^{54}$ Presiden berhak merancang RAPBN; dan RAPBN tersebut harus didiskusikan bersama dengan parlemen, seperti halnya pembahasan terhadap RUU lainnya. Apabila RAPBN ditolak oleh parlemen, maka RAPBN tahun sebelumnya akan dipakai. Oleh karena itu, Presiden tidak lagi memiliki kekuasaan legislatif yang kuat. Presiden masih memiliki veto sebagai kunci untuk menyetujui atau tidak sebuah pembahasan RUU di dalam proses pembahasan di parlemen. Hak veto Presiden tersebut meningkatkan pengaruh Presiden terhadap parlemen; utamanya dalam menghindarkan parlemen untuk meloloskan RUU yang bertentangan dengan preferensi kebijakan hukum yang dimiliki Presiden. Namun, Presiden tidak dapat menolak RUU yang sudah disetujui bersama dalam

53 Hananto Widodo et al, "The Legal Politics of the Inquiry Rights of the House of Representatives Post 1945 Constitutional Amendment" (2019) 85 J Law, Policy Glob 123-132.

54 Bagus Oktafian Abrianto, Xavier Nugraha \& Risdiana Izzaty, "Hak Konstitusional Lembaga Kepresidenan Dalam Penolakan Pengesahan RUU APBN Oleh DPR" (2019) 7:3 J IUS Kaji Huk dan Keadilan 519. 
pembahasan, meski pada akhirnya akan tetap diundangkan selama jangka waktu 30 hari. ${ }^{55}$

Tolak ukur keberhasilan suatu pemerintahan adalah ketika pemerintahan mampu menghasilkan suatu stabilitas pemerintahan yang baik. Suatu ciri pemerintahan dapat dikatakan memiliki stabilitas yang baik apabila suatu kebijakan hukum dapat di ambil dan diimplementasikan secara tepat sasaran dan tepat waktu dalam menyikapi berbagai isu-isu terkait dengan kebijakan kebijakan di bidang ekonomi, lingkungan, industri, pendidikan, perizinan, pertanahan, pertahanan, dan lain-lain. Kebijakan yang tepat sasaran tersebut memerlukan konsolidasi politik yang besar dan tidak dimungkinkan apabila tidak terjadi ketidakharmonisan antara eksekutif dan legislatif

\section{MEWUJUDKAN PEMERINTAHAN PRESIDENSIAL EFEKTIF DENGAN PRESIDENTIAL THRESHOLD}

Faktor penentu keberhasilan suatu pemerintahan presidensial yang menempatkan Presiden sebagai kepala pemerintahan sekaligus kepala negara adalah kemampuan dan profesionalitas menteri sebagai seseorang yang ditunjuk langsung oleh Presiden. ${ }^{56} \mathrm{Hal}$ itu tersebut yang menurut Jimly Asshidiqie disebut dengan istilah kabinet zakken; ${ }^{57}$ yang penunjukannya akan mengesampingkan aspek-aspek dan pertimbangan politis yang pada realitasnya banyak terjadi. Secara umum, di dalam pemerintahan sistem presidensial, pengelolaan jabatan di dalam kabinet merupakan kewenangan konstitusional Presiden; maka dari itu Presiden yang memilih menteri yang nantinya bertanggung jawab kepada Presiden, bukan pada majelis parlemen. Namun, praktik yang terjadi di banyak negara mempraktikkan sistem pemerintahan presidensial yang sangat variatif.

55 Bayu Dwi Anggono, "Omnibus Law Sebagai Teknik Pembentukan Undang-Undang: Peluang Adopsi dan Tantangannya dalam Sistem Perundang-Undangan Indonesia” (2020) 9:1 J Rechts Vinding Media Pembin Huk Nas 17.

56 Dody Nur Andriyan, "Format Kabinet Presidensial Multipartai Dalam Tata Hubungan dan Pengelolaan Pemerintahan Daerah" (2020) 3:1 Jentera J Huk 240-260 at 244 .

57 Ibid at 38. 
Variasi pengisian menteri kabinet diantaranya: ${ }^{58}$ penunjukan nama-nama menteri oleh Presiden, tanpa diperlukan pengesahan ataupun pelantikan; penunjukan nama-nama menteri oleh Presiden, dengan pengesahan serta pelantikan oleh majelis parlemen; penunjukan Perdana Menteri oleh Presiden, lalu nama-nama menteri kabinet ditentukan oleh perdana menteri; penunjukan anggota menteri kabinet dilakukan hanya atas dasar rekomendasi nama-nama calon menteri kabinet oleh majelis parlemen. Dalam penentuan kabinet di Indonesia, Presiden memiliki kewenangan yang luas dan strategis dalam menentukan atau mengisi anggota kabinet; ${ }^{59}$ karena tidak memerlukan persetujuan dari majelis parlemen seperti yang terjadi dalam pemerintahan presidensial Amerika Serikat.

Meskipun Pasal 17 UUD 1945 memberikan kekuatan penuh kepada Presiden untuk melakukan pengisian jabatan menteri; sejak perubahan UUD 1945 terkait sistem presidensialisme multipartai, kewenangan Presiden sebenarnya telah tereduksi dengan adanya praktik koalisi partai politik pendukung Presiden. ${ }^{60}$ Kewenangan Presiden untuk memilih seseorang untuk mengisi jabatan di Kementerian adalah bentuk kompromi dengan realitas politik; serta terdapat beberapa fakta empiris membuktikan bahwa Presiden akan berkompromi dalam penyusunan kabinet bersama partai pendukung pemerintah. Terjadinya instabilitas dalam pemerintahan atau terjadinya perpecahan dalam tubuh eksekutif (divided government/executive) adalah masalah praktik yang serius dalam sistem presidensial Indonesia paska perubahan UUD $1945 .{ }^{61}$ Perpecahan dalam tubuh eksekutif biasanya tidak hanya dalam jajaran Kementerian, bahkan pernah terjadi antara Presiden dan Wakil Presiden; itulah yang dimaksud oleh Saldi Isra sebagai Divided Executive. Hanta Yudha menguraikan bahwa dalam penentuan kabinet, partai politik koalisi pendukung pemerintah di DPR menuntut adanya

\footnotetext{
58 Isra, supra note 1 at 251.

59 Veri Junaidi \& Violla Reininda, "Relasi Presiden dan DPR dalam Pembentukan Undang-Undang pada Sistem Pemerintahan Presidensial Multipartai” (2020) 3:1 Jentera J Huk 216-239.

60 Hanta Yuda AR, Presidensialisme Setengah Hati (Jakarta: Gramedia Pustaka Utama, 2010) at 198.

${ }^{61}$ Isra, supra note 1 at 253.
} 
keseimbangan akomodasi kepentingan di kabinet, dan itulah yang kemudian kita kenal sebagai kabinet koalisi. ${ }^{62}$

Efektifnya sistem presidensial ditentukan oleh dua dimensi, yaitu: efektivitas sistem yakni bahwa relasi antara aktor dari institusi presidensialisme berkaitan dengan sesuai norma atau aturan yang berlaku; dan efektivitas personalia Presiden atau non-institusional; dimana menyangkut kemampuan karakter kepribadian Presiden dalam menerapkan presidensialisme sesuai aturan konstitusi. ${ }^{63}$ Perumusan sistem pemerintahan presidensial yang terkandung di dalam UUD 1945 dijabarkan secara normatif ketika dikombinasikan dengan struktur politik multipartai. Ketentuan tersebut juga mengalami dilema di dalam penerapannya; sehingga perlu adanya kompromi dengan konteks realitas dan kesatuan politik di Indonesia khususnya keniscayaan sistem multipartai (Presidensialisme Kompromis) ${ }^{64}$

Praktik Sistem Pemerintahan Indonesia merupakan ciri-ciri umum dari sistem presidensial; namun dalam sistem kepartaian yang dianut merupakan struktur multipartai, manakala secara umum hal tersebut merupakan ciri-ciri dari sistem parlementer. ${ }^{65}$ DPR dipandang memiliki kekuasaan yang lebih besar dan sering memasuki wilayah pemerintah. Pembahasan perubahan UUD 1945 mulai dilakukan oleh MPR di tahun 1999; salah satu mengenai kesepakatan dasar akan arah perubahan adalah mempertegas sistem presidensial dalam penyelenggaraan pemerintahan agar prinsip-prinsip dasar sistem presidensial benar-benar terlaksana.

Saldi Isra pernah menjelaskan pendapat Aulia A. Rachman mengenai gagasan MPR hasil Pemilu 1999, terkait alasan mempertahankan sekaligus melakukan purifikasi sistem presidensial. ${ }^{66}$ Pertama, format sistem presidensial yang ada di Indonesia merupakan kesepakatan yang didasarkan atas kepentingan para pendiri negara tahun 1945; meskipun formatnya tidak

62 AR, supra note 60 at 198.

63 Ibid at 59.

64 Retno Saraswati, Desain Sistem Pemerintahan Presidensial yang Efektif (Semarang: Universitas Diponegoro, 2012) at 141.

65 Edie Toet Hendratno, Sistem Presidensial Dalam Multipartai: Mendesain Sistem Pemerintahan Presidensial yang Efektif (Jakarta: Universitas Pancasila, 2014) at 83.

${ }^{66}$ Isra, supra note 1 at 149. 
sama dengan sistem presidensial umumnya. Kedua, pengalaman traumatis bangsa Indonesia, ketika pemberlakuan sistem parlementer berdasarkan UUD Sementara 1950. Ketiga, sistem pemerintahan parlementer dianggap sebagai pemikiran demokrasi liberal. Keempat, sistem pemerintahan presidensial menciptakan stabilitas pemerintahan. Kelima, pemilihan secara langsung dapat hasilkan pemerintahan yang legitimate; oleh karena mendapat mandat langsung dari rakyat.

Sistem pemerintahan presidensial yang diterapkan di negara-negara di dunia dapat saja mengalami perbedaan. Sehingga, sebagian ada yang menerapkan presidensial dengan sistem dua partai dan sistem multipartai. ${ }^{67}$ Dampak yang terjadi akibat penerapan multipartai ialah tingkat pembagian kepartaian yang rendah serta kekuatan politik di parlemen yang terfragmentasi. Konsekuensi dari hal itu, partai akan cenderung berkoalisi; baik untuk mendukung pemerintah ataupun menjadi oposisi pemerintah. Penentuan kabinet oleh Presiden pada akhirnya juga akan mempertimbangkan kehendak dari tuntutan kepentingan pengisian jabatan menteri dari partai koalisi pendukung pemerintah.

Pemberlakuan syarat ambang batas perolehan suara partai politik atau gabungan partai politik dalam mengusulkan calon presiden dan wakil presiden (presidential threshold), bukan hanya akan memberikan gambaran terkait suara pendukung presiden di DPR; tetapi juga siapa saja nama-nama yang akan mengisi personalia di kabinet. Tentunya, hal tersebut akan dibicarakan secara intensif oleh partai-partai pendukung sebelum pelaksanaan Pemilu. ${ }^{68}$ Dengan pembicaraan intensif serta kontrak kontrak politik bersamaan dengan partai pengusung di antara calon Presiden dan Wakil Presiden; tentu akan melahirkan kabinet koalisi.

Selain melalui dukungan parlemen yang melahirkan kabinet koalisi, personalitas, dan gaya kepemimpinan, Presiden juga akan memengaruhi efektivitas pemerintahan presidensial. Sistem politik multipartai serta struktur konstitusi presidensial ini akan memengaruhi corak serta perilaku institusi kepresidenan. Scott Mainwaring berpendapat bahwa terdapat

67 Saraswati, supra note 64 at 138.

${ }^{68}$ Isra, supra note 1 at 245. 
empat penganut sistem presidensial yang berhasil menciptakan pemerintahan yang stabil dan efektif. Ke-empat negara yang dimaksud Mainwaring adalah Amerika Serikat, Kostarika, Kolombia, dan Venezuela. ${ }^{69}$ Di samping itu, negara-negara dengan sistem parlementer juga dinilai sukses untuk menjaga stabilitas dan efektifitas pemerintahan. Negara-negara tersebut adalah Astralia, Jerman, Austria, Belgia, Denmark, Kanada, Irlandia, Inggris, Belanda, Selandia Baru, dan sebagainya.

Sistem presidensial Amerika Serikat dengan two party system mampu menghasilkan pemerintahan yang jauh lebih efektif; apabila dibandingkan dengan sistem presidensial dengan sistem multipartai. Ada beberapa alasan yang mendasari mengenai sistem presidensial; 'mengapa' sistem tersebut kurang cocok untuk menghasilkan pemerintahan yang efektif dan stabil apabila disandingkan dengan sistem multipartai. Apabila dibandingkan dengan ssstem parlementer; sistem multipartai justru akan lebih dapat menciptakan pemerintahan yang efektif dan stabil. Arif Wibowo dalam tesisnya mengutip pendapat MJ. Hoffler; yang menyatakan bahwa banyak pihak seringkali berputus asa bahwa penyebab utama terjadinya ketidakstabilan politik di dalam sistem multipartai oleh karena adanya banyak partai; sehingga parlementer terfragmentasi. ${ }^{70}$ Padahal, Pemilu yang proporsional merupakan penyebab sistem multipartai; oleh karena guna menghindari ketidakstabilan politik, maka sistem Pemilu proporsional harus ditolak.

Kenneth Koford dan Linda Heckert juga melakukan penelitian terhadap sistem politik Perancis dari parlementer menuju ke presidensial; ${ }^{71}$ khususnya perihal jumlah partai politik. Peralihan sistem dari parlementer ke presidensial tersebut diikuti dengan perubahan sistem Pemilu proporsional dan distrik. Hasil penelitian Kenneth Koford dan Linda Heckert tersebut menunjukkan bahwa jumlah partai politik tidak berkurang dan jumlahnya tetap tinggi selama periode republik kelima; yang dibuktikan dari jumlah

${ }^{69}$ Ibid at 141.

70 Arif Wibowo, Pemilihan Umum Setelah Perubahan Undang Undang Dasar 1945 Menuju Sistem Pemerintahan Presidensial Efektif, Universitas Jember, 2018).

71 Kenneth Koford \& Linda Heckert, "Determinants of the Number of Legislative Parties: Evidence from Postwar France" in (1987) 371. 
partai politik efektif di parlemen masih lebih dari tiga. Kenneth Koford dan Linda Heckert berpandangan bahwa di samping sistem aturan politik atau sistem Pemilu; ${ }^{72}$ ternyata nilai-nilai politik dan tradisi politik juga berperan untuk menjelaskan mengapa jumlah partai politik tetap besar.

\section{KESIMPULAN}

Ketentuan presidential threshold sejatinya telah dilakukan sejak perhelatan Pemilu 2004; sebagaimana amanat dari UU Pilpres I. Hingga saat ini, ketentuan presidential threshold tetap dipertahankan dan mengalami perubahan pada aspek presentase minimal ambang batas. Ketentuan presidential threshold juga tercantum dalam UU Pilpres II dan UU Pemilu. Kendati demikian, presidential threshold kerap kali diuji pada MK. Namun, berbagai PMK menyatakan bahwa presidential threshold adalah ketentuan yang berada dalam ranah pembuat UU (Open Legal Policy). Politik hukum diaturnya ambang batas Pencalonan Presiden dan Wakil Presiden adalah untuk mewujudkan stabilitas pemerintahan presidensial; khususnya dalam konteks ditinjau dari adanya hubungan koalisi pendukung pemerintah antara Presiden dan DPR.

\section{DAFTAR PUSTAKA}

Anggono, Bayu Dwi, Perkembangan Pembentukan Undang Undang di Indonesia (Jakarta: Penerbit Konstitusi Press, 2014).

Ansori, Lutfil, Legal Drafting (Teori dan Praktik Penyusunan PerundangUndangan) (Depok: PT RajaGrafindo Persada, 2019).

AR, Hanta Yuda, Presidensialisme Setengah Hati (Jakarta: Gramedia Pustaka Utama, 2010).

Hendratno, Edie Toet, Sistem Presidensial Dalam Multipartai: Mendesain Sistem Pemerintahan Presidensial yang Efektif (Jakarta: Universitas Pancasila, 2014).

Isra, Saldi, Sistem Pemerintahan Indonesia, 1 ed (Depok: PT RajaGrafindo Persada, 2019).

${ }^{72}$ Ibid. 
Marzuki, Peter Mahmud, Penelitian Hukum: Edisi Revisi, 13 ed (Jakarta: KENCANA, 2017).

Saraswati, Retno, Desain Sistem Pemerintahan Presidensial yang Efektif (Semarang: Universitas Diponegoro, 2012).

Wibowo, Arif, Pemiliban Umum Setelah Perubahan Undang - Undang Dasar 1945 Menuju Sistem Pemerintahan Presidensial Efektif (Universitas Jember, 2018).

Abrianto, Bagus Oktafian, Xavier Nugraha \& Risdiana Izzaty, "Hak Konstitusional Lembaga Kepresidenan Dalam Penolakan Pengesahan RUU APBN Oleh DPR” (2019) 7:3 J IUS Kaji Huk dan Keadilan 519.

Al-Fatih, Sholahuddin, "Akibat Hukum Regulasi Tentang Threshold Dalam Pemilihan Umum Legislatif dan Pemilihan Presiden” (2019) 12:1 J Yudisial 17.

Alder, Jonathan H \& Christopher J Walker, "Delegation and Time" (2019) 105 Iowa Law Rev 7.

Amir, Mushaddiq, "Keserentakan Pemilu 2024 yang Paling Ideal Berdasarkan Putusan Mahkamah Konstitusi Republik Indonesia” (2020) 23:2 Al-Ishlah J Ilm Huk 115-131.

Andrian Habibi, "Upaya Menyelamatkan Pemilihan Umum Di Tahun 2020tle" (2020) 4:1 Adalah Bul Huk Keadilan 167-172.

Andriyan, Dody Nur, "Format Kabinet Presidensial Multipartai Dalam Tata Hubungan dan Pengelolaan Pemerintahan Daerah" (2020) 3:1 Jentera J Huk 240-260.

Anggono, Bayu Dwi, “Omnibus Law Sebagai Teknik Pembentukan Undang-Undang: Peluang Adopsi dan Tantangannya Dalam Sistem Perundang-Undangan Indonesia” (2020) 9:1 J Rechts Vinding Media Pembin Huk Nas 17.

_- "Perspektif Konstitusi Indonesia pada Kerjasama Partai Politik dalam Pemilihan Presiden dan Wakil Presiden” (2014) 9:1 Pandecta Res Law J 92-112.

__ , "Tertib Jenis, Hierarki, Dan Materi Muatan Peraturan PerundangUndangan: Permasalahan dan Solusinya" (2018) 47:1 Masal Huk 1-9.

Budiatri, Aisah Putri, "Pemilu Presiden Amerika Serikat" (2013) 10:2 J Penelit Polit 163-175.

Diniyanto, Ayon, "Mengukur Dampak Penerapan Presidential Threshold di 
Pemilu Serentak Tahun 2019” (2018) 1:1 Indones State Law Rev 8390.

Effendhy, M Rizky Andika Pratama Putra \& Moh Haris Lesmana, "Formulasi Konsep Single Presidential Treshold Dalam Pemilu Serentak Sebagai Upaya Memperkuat Sistem Pemerintahan Presidensial Di Indonesia” (2019) 2:2 Legislatif 1-23.

Elwan, La Ode Muhammad, "Penataan Ulang Sistem Legislasi: 'Efektifitas Hak Veto Presiden Dalam Sistem Pemerintahan di Indonesia Berdasarkan UUD NRI Tahun 1945”' (2018) 4:3 Rezpublica 1-13.

Fadli, Muhammad, "Pembentukan Undang-Undang Yang Mengikuti Perkembangan Masyarakat" (2018) 15:1 J Legis Indones 49-58.

Ghoffar, Abdul, "Problematika Presidential Threshold: Putusan Mahkamah Konstitusi dan Pengalaman di Negara Lain" (2018) 15:3 J Konstitusi 480-501.

Gordon, Aaron, "Nondelegation” (2019) 12:3 NYU J Law Lib 799.

Indarja, Indarja, "Perkembangan Pemilihan Presiden Dan Wakil Presiden Di Indonesia" (2018) 47:1 Masal Huk 63.

Junaidi, Veri \& Violla Reininda, "Relasi Presiden dan DPR dalam Pembentukan Undang-Undang pada Sistem Pemerintahan Presidensial Multipartai” (2020) 3:1 Jentera J Huk 216-239.

Kawamura, Koichi, "President Restrained: Effects of Parliamentary Rule and Coalition Government on Indonesia's Presidentialism" in Pres Assem Policy-making Asia (London: Palgrave Macmillan UK, 2013) 156.

Koford, Kenneth \& Linda Heckert, "Determinants of the Number of Legislative Parties: Evidence from Postwar France" in (1987) 371.

Kurnia, Titon, "Presidential Candidacy Threshold and Presidentialism Affirmation in Indonesia" (2021) 07:03 PADJADJARAN J Ilmu Huk (Journal Law) 353-379.

Kusnadi, Kuswanto, "Mahkamah Konstitusi Dan Upaya Menegakkan Asas Presidensialisme Di Indonesia” (2020) 5:1 Refleks Huk J Ilmu Huk 120.

Pradnyana, Dewa Putu Wahyu Jati, I Gede Yusa \& Ni Luh Gede Astariyani, "Analisa Hukum Ambang Batas Pencalonan Presiden (Presidential Threshold) Dalam Undang-Undang Republik Indonesia Nomor 7 
Tahun 2017 Tentang Pemilihan Umum” (2018) 6:4 Kertha Negara J Ilmu Huk 1-13.

Prayitno, Cipto, "Analisis Konstitusionalitas Batasan Kewenangan Presiden dalam Penetapan Peraturan Pemerintah Pengganti Undang-Undang" (2020) 17:3 J Konstitusi 513-529.

R, Dri Utari C, "Menakar Kohabitasi Perancis dalam Mekanisme Koalisi Oposisi Pasca Pemilu Serentak 2019” (2020) 3:1 J Jentera 261-290.

Sarjan, Sarjan, Kemal AL Kindi Mulya \& Siti Chadijah, "Problematika Dan Teknis Penyelengaraan Pemilihan Kepala Daerah Pada Masa Pandemi Covid 19" (2020) 3:1 Rechtsregel J Ilmu Huk 59.

Satriawan, Iwan \& Tanto Lailam, "Open Legal Policy dalam Putusan Mahkamah Konstitusi dan Pembentukan Undang-Undang” (2019) 16:3 J Konstitusi 559-584.

Subhi, Ahmad Farhan, "Pengusulan Pasangan Calon Presiden Dan Wakil Presiden Sebagai Peserta Pemilu Menurut Undang-Undang Pilpres" (2016) 3:2 J CITA Huk 339-352.

Sukimin, Sukimin, "Pemilihan Presiden Dan Wakil Residen Berdasarkan Undang-Undang Republik Indonesia Nomor 7 Tahun 2017 Tentang Pemilihan Umum" (2020) 3:1 J USM Law Rev 112.

Sulkiah, Sulkiah, "Pelaksanaan Hak Prerogatif Presiden dalam Penyusunan Kabinet Berdasarkan Pasal 17 UUD 1945 Amandemen Suatu Tinjauan Sistem Ketatanegaraan Indonesia" (2020) 2:1 Nurani Huk 42.

Syahuri, Taufiqurrohman \& Muhammad Helmi Fahrozi, "Konstitusionalitas Pasal 222 Uu Nomor 7 Tahun 2017 Tentang Pemilu (Presidential Treshold)” (2020) 1:1 Al Wasath J Ilmu Huk 2534.

Tuswoyo, "Pelembagaan Oposisi Dalam Sistem Presidensial: Studi Tentang Oposisi PDIP di DPR” (2013) 1:1 JISPO (Jurnal Ilmu Sos dan Ilmu Polit 132-155.

Wibowo, Mardian, "Menakar Konstitusionalitas sebuah Kebijakan Hukum Terbuka dalam Pengujian Undang-Undang” (2016) 12:2 J Konstitusi 196.

Widodo, Hananto, "The Legal Politics of the Inquiry Rights of the House of Representatives Post 1945 Constitutional Amendment" (2019) 85 J Law, Policy Glob 123-132. 
Zamroni, Mohammad, "Kekuasaan Presiden dalam Mengeluarkan Perppu (President's Authority to Issue Perppu)” (2015) 12:3 J Legis Indones 1-38.

RI, DPR, Risalah Rapat Proses Pembahasan Rancangan Undang-Undang tentang Pemiliban Presiden dan Wakil Presiden (Jakarta, 2003).

Tim Penyusun Naskah Komprehensif dan Proses dan Hasil Perubahan UUD 1945, Naskah Komperehensif Perubahan Undang-Undang Dasar Negara Republik Indonesia tahun 1945 Buku X Perubahan, Aturan Peraliban, dan Aturan Tambahan, Edisi Revisi (Sekretariat Jendral dan Kepaniteraan Mahkamah Konstitusi, 2010). 